\title{
Offline Programming for Robotic Deburring Process of Aluminium Wheels
}

Ondrej Bilek, David Samek, Jana Knedlova

Tomas Bata University in Zlin, Faculty of Technology, Department of Production Engineering, T. G. Masaryka 5555,

76001 Zlin, Czech Republic. bilek@ft.utb.cz

The paper presents application of Siemens RobotExpert software of industrial robot offline programming. The deburring process of aluminium wheel is described and developed. The robotic work-cell contains robot ABB IRB 1600id and two axes positioner ABB IRBP A $750 \mathrm{D} 1000 \mathrm{H} \mathrm{700}$. The final robot tool path is checked using the collision viewer, the joint status monitor, the tool centre point speed viewer and tracker.

Keywords: Deburring, RobotExpert, Aluminium, Offline Programming, Wheels.

\section{References}

[1] AURICH, J. C., DORNFELD, D., ARRAZOLA, P. J., FRANKE, V., LEITZ, L., MIN, S. (2009). Burrs-analysis, control and removal. In: CIRP Annals-Manufacturing Technology, Vol. 58, No. 2, pp. 519-542. CIRP.

[2] BOLIBRUCHOVA, D., RICHTARECH L. (2013). Study of the gas content in aluminum alloys, In: Manufacturing Technology, Vol. 13, No. 1, pp. 14-20. UJEP. Usti nad Labem.

[3] BRUNA, M., KUCHARCIK, L., SLADEK, A. (2013). Complex evaluation of porosity in A356 aluminium alloy using advanced porosity module, In: Manufacturing Technology, Vol. 13, No. 1, pp. 26-30. UJEP. Usti nad Labem.

[4] DANISOVA, N., RUZAROVSKY, R., VELISEK, K. (2013) Designing of intelligent manufacturing assembly cell by moduls of system catia and E-Learning module creation, In: Advanced Materials Research, Vol. 628, pp. 283-286. TTP. Switzerland.

[5] DIETZ, T., SCHNEIDER, U., BARHO, M., OBERER-TREITZ, S., DRUST, M., HOLLMANN, R., HÄGELE, M. (2012). Programming System for Efficient Use of Industrial Robots for Deburring in SME Environments. In: Robotics; Proceedings of ROBOTIK 2012; 7th German Conference on, pp. 1-6. VDE.

[6] HOLUBEK, R., VELISEK, K. (2013). Incorporation, programming and use of an ABB robot for the operations of palletizing and depalletizing at an academic research oriented to intelligent manufacturing cell, In: Applied Mechanics and Materials, Vol. 282, pp. 127-132. TTP. Switzerland.

[7] HRUBY, J., RENTKA, J., SCHINDLEROVA, V., KREJCI, L., SEVCIKOVA, X. (2013). Possibilities of prediction of service life of forming tools, In: Manufacturing Technology, Vol. 13, No. 2, pp. 178-181. UJEP. Usti nad Labem.

[8] JAYAWEERA, N., WEBB, P. (2010). Measurement assisted automated robotic edge deburring of complex components. In: Proceedings of the 9th WSEAS international conference on Signal processing, robotics and automation, pp. 133-138. World Scientific and Engineering Academy and Society, Cambridge.

[9] KOSTAL, P., VELISEK, K. (2011). Flexible manufacturing system, In: World Academy of Science, Engineering and Technology, Vol. 77, pp. 825-829. WASET. Las Cruces.

[10] MENZIE, W. D. (2010). The global flow of aluminum from 2006 through 2025, US Department of the Interior, US Geological Survey.

[11] MEURER, B., HAFERKAMP, D., JORG, A. (2001). Use of simulation in the production of cast aluminium wheels. In: CASTING PLANT AND TECHNOLOGY INTERNATIONAL, Vol. 17, No. 3, pp. 14-23. Solingen.

[12] NOVA, I., MACHUTA, J. (2013). Squeeze casting results of aluminium alloys, In: Manufacturing Technology, Vol. 13, No. 1, pp. 73-79. UJEP. Usti nad Labem.

[13] PAN, Z., POLDEN, J., LARKIN, N., VAN DUIN, S., NORRISH, J. (2012). Recent progress on programming methods for industrial robots. In: Robotics and Computer-Integrated Manufacturing, Vol. 28, No. 2, pp. 87-94.

[14] SADILEK, M., CEP, R., BUDAK, I., SOKOVIC, M. (2011). Aspects of using tool axis inclination angle, In: Strojniski Vestnik/Journal of Mechanical Engineering, Vol. 57, No. 9, pp. 681-688. University of Ljubljana. Ljubljana.

[15] STAS, O., TOLNAY, M., MAGDOLEN, L. (2010). Artificial intelligence in analysis of fast dynamic actions, In: ASME 2010 10th Biennial Conference on Engineering Systems Design and Analysis, ESDA2010, pp. 885-889. Yeditepe University, Istanbul. 
[16] MICHNA, S., NAPRSTKOVA, N. (2012). Research into the causes cracking of aluminum alloys of $\mathrm{Al}-\mathrm{Cu}$ during mechanical machining, In: Manufacturing Technology, Vol. 12, No. 12, pp. 47-51. UJEP. Usti nad Labem.

[17] ZHANG, H., et al. (2006). On-line path generation for robotic deburring of cast aluminum wheels. In: Intelligent Robots and Systems, IEEE/RSJ International Conference on, pp. 2400-2405. IEEE, Beijing.

[18] ZILIANI, G.; VISIOLI, A.; LEGNANI, G. (2007). A mechatronic approach for robotic deburring. In: Mechatronics, Vol. 17, No. 8, pp. 431-441. Elsevier. 